\title{
In Vitro Sulfotransferase Activity of NoeE, a Nodulation Protein of Rhizobium sp. NGR234
}

\author{
D. Quesada-Vincens, M. Hanin, W. J. Broughton, and S. Jabbouri \\ Laboratoire de Biologie Moléculaire des Plantes Supérieures, Université de Genève, $1 \mathrm{ch}$. de l'Impératrice, \\ 1292 Chambésy/Genève, Switzerland \\ Accepted 27 March 1998.
}

Soil bacteria of the genera Azorhizobium, Bradyrhizobium, and Rhizobium liberate morphogenetic lipochitin-oligosaccharides (Nod factors) into legume rhizospheres. Nod factors, which are synthesized by the products of rhizobial nodulation (nod) genes, vary in core length as well as in the number and type of substitutions. In Rhizobium sp. NGR234, the $\mathrm{N}$-acylated pentamers of $\mathrm{N}$-acetyl-Dglucosamine carry an $O$-methylfucose group on the reducing terminus that is substituted, on a mutually exclusive basis, with either an acetyl or a sulfuryl group. A sulfotransferase encoded by $n o e E$ is required for adjunction of activated sulfate donated by $3^{\prime}$-phosphoadenosine $5^{\prime}$ phosphosulfate (PAPS). Here we show that when expressed in NGR234 cured of its symbiotic plasmid (= ANU265) or when purified as a fusion protein (MBPNoeE), NoeE transfers sulfate from PAPS to fucosylated lipochitin-oligosaccharides. Enzyme assays showed that sulfotransferase activity is dependent on the presence of an acyl group (stearic and vaccenic acids were tested) since no activity was detected when fucosylated oligochitins (oligomers of two to six $\mathrm{N}$-acetyl-D-glucosamine units) were used as substrates. Thus, NoeE is unique in that it is the only characterized sulfotransferase that is specific for fucosylated Nod factors. It probably acts after $\operatorname{NodA}$, which acylates the amino-sugar backbone.

Symbiotic interactions between rhizobia and legumes are based on the exchange of specific signals. In response to flavonoids released by the plant, rhizobia synthesize and excrete lipochitin-oligosaccharides (LCOs), called Nod factors (for recent reviews, see Hanin et al., in press; Mergaert et al. 1997; Schultze and Kondorosi 1996). Nod factors are mitogens (Truchet et al. 1991) that also induce membrane depolarization (Ehrhardt et al. 1992), rapid elevations in intracellular free calcium (Ehrhardt et al. 1996; Gehring et al. 1997), root-hair deformation (Heidstra et al. 1994; Price et al. 1992), and entry of bacteria into their hosts (Relić et al. 1994). Together, these responses lead to the formation of root nodules in which differentiated rhizobia reduce atmospheric nitrogen to ammonia.

Corresponding author: W. J. Broughton, Laboratoire de Biologie Moléculaire des Plantes Supérieures, Université de Genève, 1 ch. de l'Impératrice, 1292 Chambésy/Geneva, Switzerland; Telephone: +41 22 90617 40; Fax: +41 2290617 41; E-mail: broughtw@sc2a.unige.ch
Many nod (or nol and noe) gene products are involved in the synthesis of Nod factors. NodA, NodB, and NodC are required for the synthesis of the Nod-factor "core" (Atkinson et al. 1994; Geremia et al. 1994; Spaink et al. 1994), which consists of oligomers of three to six $\mathrm{N}$-acetylD-glucosamine residues (GlcNAc) that are $\mathrm{N}$-acylated at the nonreducing terminus. Specific nod genes are for the most part responsible for the decoration of the Nod-factor backbone in which various adjuncts are added to both termini. These include $O$-acetyl, $O$-carbamoyl, and $N$-methyl groups as well as various fatty acids at the nonreducing end. Acetyl, arabinosyl, fucosyl, or sulfuryl, and, less commonly, glyceryl or mannosyl groups are present on the reducing sugar (Dénarié et al. 1996). Such substitutions vary from one $R h i$ zobium sp. to another and play an important role in the control of the host range. As an example, mutation of nodH of $R$. meliloti abolishes the production of sulfated Nod factors as well as the ability to nodulate the homologous host Medicago sativa. On the other hand, NodH mutants are able to nodulate the heterologous legume Vicia sativa (Faucher et al. 1988; Roche et al. 1991). nodS encodes an N-methyltransferase that is specific for the nonmethylated products of the nodBC genes (Jabbouri et al. 1995; Geelen et al. 1995; Waelkens et al. 1995). A functional nodS gene is required for nodulation of Leucaena leucocephala (Lewin et al. 1990; Krishnan et al. 1992).

Sulfated Nod factors are found in Rhizobium sp. NGR234 (Price et al. 1992), Rhizobium sp. N33 (Cloutier et al. 1996), $R$. tropici (Poupot et al. 1993; Laeremans et al. 1996; FolchMallol et al. 1996), and Sinorhizobium teranga bv. acaciae strains ORS1602 and ORS1645 (Lorquin et al. 1997). The nodPQ genes of $R$. meliloti are required for sulfation of NodRm factors (Roche et al. 1991). NodP and NodQ form a multi-functional complex that possesses both ATP sulfurylase and adenosine $5^{\prime}$-phosphosulfate (APS) kinase activities. Activities of both enzymes are necessary for the synthesis of 3'phosphoadenosine 5'-phosphosulfate (PAPS), the sulfate donor (Schwedock et al. 1994). In vitro assays show that NodH catalyzes the transfer of sulfate from PAPS to C- 6 of the reducing GlcNAc of NodRm factors (Schultze et al. 1995; Ehrhardt et al. 1995). Recent genetic and chemical data suggest that sulfation of NodNGR factors is dependent on noeE (Hanin et al. 1997). In continuation of this work, we show here that NoeE purified as a fusion protein acts only on entire, fucosylated Nod factors. 


\section{RESULTS}

In vitro activity of NoeE.

noeE was placed under the control of the transcriptional activator nodD1 (Hanin et al. 1997) by cloning it and its associated nod box into a broad-host-range vector (giving $\mathrm{pMZBgH}$ ). To enable induction of noeE expression by flavonoids, it was necessary, however, to conjugate this plasmid into ANU265 (= NGR234 cured of its symbiotic plasmid) along with nodD1, which is carried on the plasmid pA28 (Price et al. 1992). Crude extracts of this construct, ANU265(pA28,pMZBgH), and ANU265(pA28) (negative control) were tested for their capacity to transfer sulfate from PAPS to the fucose moiety of Nod factors.

First, sulfotransferase activity was assayed with USDA257 Nod factors (Nod $R f$ factors) as substrates. Nod $R f$ factors are mainly mixtures of trimers, tetramers, and pentamers of GlcNAc acylated with vaccenic acid. Unlike the LCOs of NGR234, the 2-O-methylfucose (or fucose) is not substituted (Bec-Ferté et al. 1994), and for this reason they are particu- larly convenient substrates for NoeE. Cell-free extracts of ANU265 (pA28,pMZBgH) and ANU265(pA28) were incubated at $27^{\circ} \mathrm{C}$ for $2 \mathrm{~h}$ with $\left[{ }^{35} \mathrm{~S}\right] \mathrm{PAPS}$. The reaction products were subjected to $\mathrm{C}_{18}$ reverse-phase thin-layer chromatography (TLC) (Fig. 1). Controls consisted of NodNGR factors labeled in vivo with $\mathrm{D}-\left[{ }^{14} \mathrm{C}\right]$ glucosamine. The major spot at $\mathrm{Rf}$ (retardation factor) $\cong 0.62$ corresponds to NodNGR factors that are either acetylated or nonsubstituted on the 2-O-methylfucose (Fig. 1A, lane 1 , spot a) while spot b $(\mathrm{Rf} \cong 0.86)$ corresponds to sulfated Nod factors (Fig. 1A, lane 1, spot b) (Price et al. 1992). Interestingly, extracts prepared from apigenin-induced ANU265(pA28,pMZBgH) cultures also possess a compound that migrates to about the same position as spot b (Fig. 1A, lane 2). This spot was absent when extracts from ANU265(pA28) were used (Fig. 1A, lane 3). Thus, NoeE is responsible for the in vitro transfer of sulfate from PAPS to USDA257 NodRf. The slightly lower migration rate of sulfated NodRf factors is probably due to fact that they are less oligomerized than those of NGR234, containing three and four GlcNAc's, which makes them more hydrophobic than those with five.
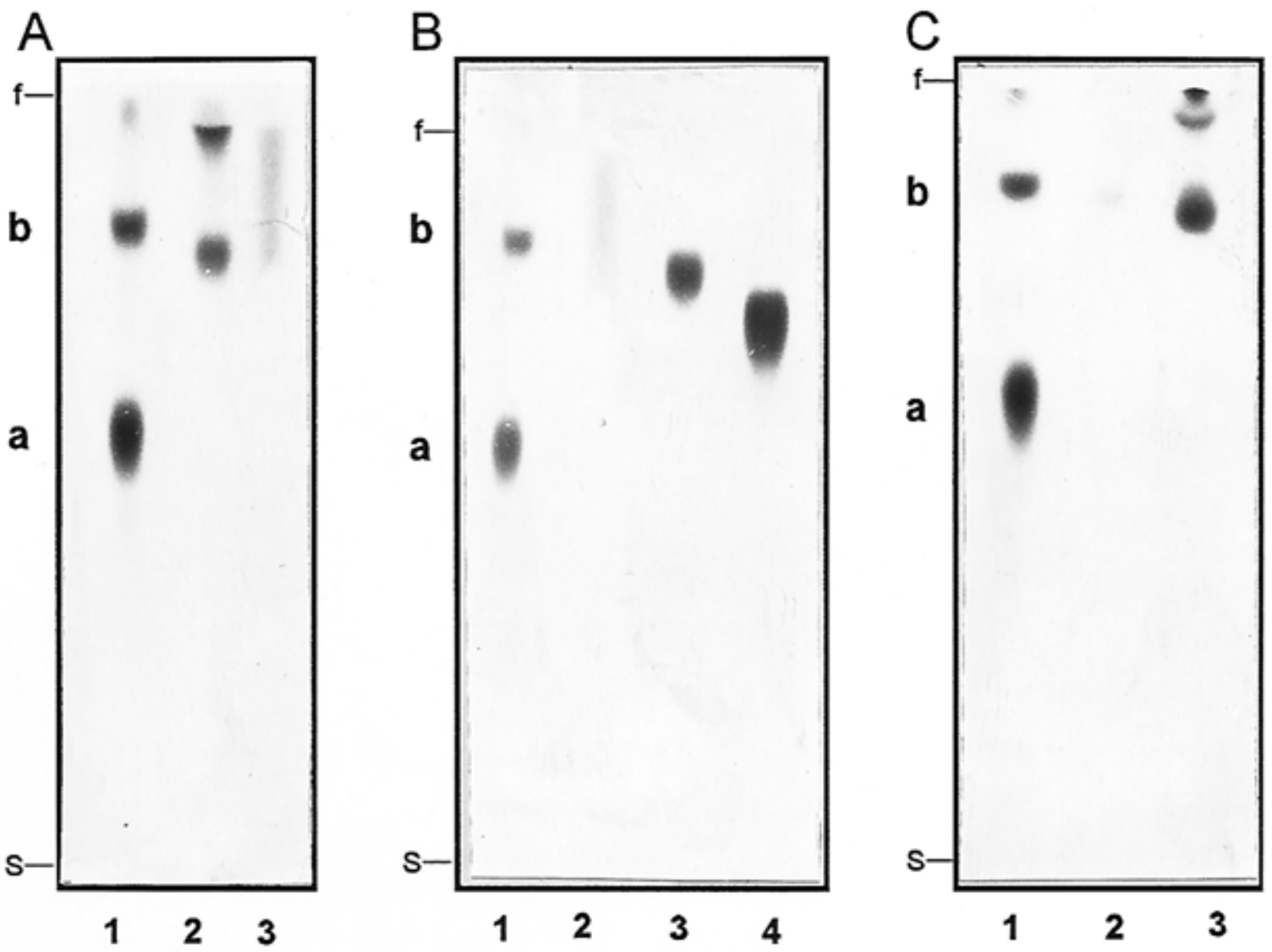

Fig. 1. Silica-gel, thin-layer chromatography (TLC) analysis of noeE-dependent activity. Cell-free extracts of (A, lane 2; B, lanes 3 and 4; C, lane 2) ANU265(pA28,pMZBgH) or (A, lane 3; B, lane 2) ANU265(pA28) were incubated with [ $\left.{ }^{35} \mathrm{~S}\right] 3^{\prime}$-phosphoadenosine $5^{\prime}$-phosphosulfate (PAPS) and various substrates. After incubation, Nod factors were recovered on $\mathrm{C}_{18}$-SepPack cartridges and eluted with methanol. Portions of the methanolic fraction were spotted onto $\mathrm{C}_{18}$-coated silica plates. Nod factors of NGR234 labeled with D- $\left[{ }^{14} \mathrm{C}\right]$ glucosamine produced in vivo by whole cells of NGR234 were loaded as a standard onto lane 1 . A, B, and $\mathbf{C}$, Spot a corresponds to Nod factors that are either acetylated or nonsubstituted on the 2-O-methylfucose; spot b corresponds to sulfated Nod factors (Hanin et al. 1997). A mixture of Nod factors taken from Rhizobium fredii strain USDA257 was used as substrate and incubated with protein extracts of (A, lane 2) ANU265(pA28,pMZBgH) or (A, lane 3; B, lane 2) ANU265(pA28). Purified, deacetylated NodNGR factors V (N-Me; MeFuc) acylated by (B, lane3) $\mathrm{C}_{18: 1}$ or (B, lane 4) $\mathrm{C}_{18: 0}$ were used as substrates. C, Comparison of NoeE and NodH sulfo-

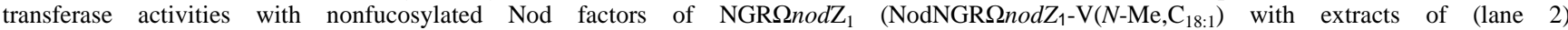
ANU265(pA28,pMZBgH) and (lane 3) NGR $\Omega$ noeE(pGMI449). The spot that migrates close to solvent front in lanes A2 and C3 originates from radioactive PAPS. ( $\mathrm{s}=$ start point of migration; $\mathrm{f}=$ solvent front $)$. 
Whereas sulfated NodNGR factors are acylated with $\mathrm{C}_{16: 1}$ or $\mathrm{C}_{18: 1}$, (Hanin et al. 1998), the nonsulfated forms may also possess a $\mathrm{C}_{18: 0}$ fatty acid ( $\mathrm{S}$. Berck, unpublished). To test whether modification of the nonreducing terminus prevents recognition of the substrate by NoeE, NodNGR-V $(N-\mathrm{Me}$, MeFuc $)\left(\mathrm{C}_{18: 0}\right)$ or NodNGR-V $(N-\mathrm{Me}, \mathrm{MeFuc})\left(\mathrm{C}_{18: 1}\right)$ factors were prepared from those of the wild-type bacterium by mild alkaline hydrolysis. Absence of the acetyl and carbamoyl groups was verified by ${ }^{13} \mathrm{C}$ - and ${ }^{1} \mathrm{H}-\mathrm{NMR}$ (Jabbouri et al., in press). When added to the in vitro system described above, NoeE sulfated both NodNGR-V $(N-M e F u c)\left(\mathrm{C}_{18: 0}\right)$ and NodNGR-V(N-MeFuc) $\left(\mathrm{C}_{18: 1}\right)$ factors (Fig. 1B, lanes 3 and 4$)$. Due to their increased hydrophobicity, $\mathrm{C}_{18: 0} \mathrm{~N}$-acylated LCOs migrate at a slightly slower $\mathrm{Rf}$ than the corresponding $\mathrm{C}_{18: 1}$ acylated ones.

In contrast to NodH, which is able to sulfate fucose and the reducing GlcNAc of LCOs, NoeE is unable to sulfate nonfucosylated Nod factors in vivo (Hanin et al. 1997). To see if this is also true in vitro, Nod factors produced by

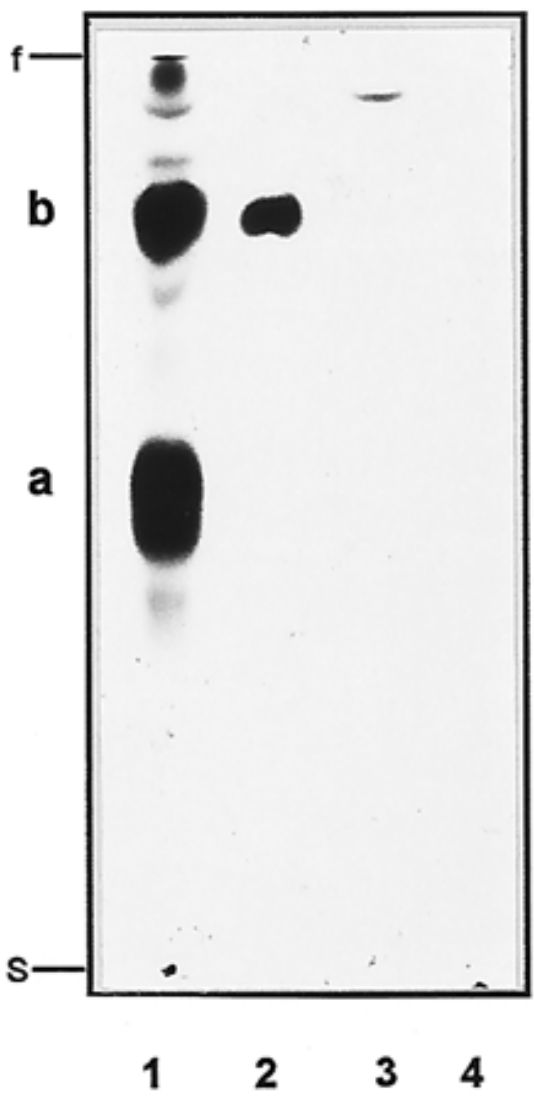

Fig. 2. Thin-layer chromatography (TLC) analysis (with $\mathrm{C}_{18}$-coated silica) of the intracellular location of NoeE activity. The (lane 2) cytosolic and (lane 3) membrane fractions of ANU265(pA28,pMZBgH) were incubated with $\left[{ }^{35} \mathrm{~S}\right] 3^{\prime}$-phosphoadenosine $5^{\prime}$-phosphosulfate (PAPS) and deacetylated NodNGR factors [NodNGR-V ( $N$-Me, $\mathrm{C}_{18: 1}$, MeFuc)]. After $2 \mathrm{~h}$ of incubation, Nod factors were recovered with a $\mathrm{C}_{18}$-SepPack. Lane 1, NodNGR factors labeled in vivo with $\mathrm{D}-\left[{ }^{14} \mathrm{C}\right]$ glucosamine (control): spot a corresponds to Nod factors that are either acetylated or nonsubstituted on the methylfucose; spot b represents sulfated Nod factors (Hanin et al. 1997). As the spot, which migrates with the solvent front, only appeared sporadically, it is considered nonsignificant. Lane 4, NodNGR-V(N-Me, $\left.\mathrm{C}_{18: 1}, \mathrm{MeFuc}\right)$ factors were incubated with ANU265(pA28). ( $\mathrm{s}=$ start point of migration; $\mathrm{f}=$ solvent front).
NGR $\Omega \operatorname{nodZ}_{1}$, which completely lack fucose (QuesadaVincens et al. 1997), were incubated with cell-free extracts of ANU265(pA28,pMZBgH) and $\left[{ }^{35}\right.$ S]PAPS. TLC analyses of the reaction products revealed traces of radioactivity in nonfucosylated Nod factors (Fig. 1C, lane 2), suggesting that they are not good substrates for NoeE. Substrate specificities of NodH and NoeE were compared by incubating cell-free extracts of NGRAnoeE(pGMI449)(nodH) with fucosylated NodNGR-V(N-Me,MeFuc, $\left.\mathrm{C}_{18: 1}\right)$ factors. In NGR $\Delta$ noeE (pGMI449), transcriptional activation of nodH occurs via its own promoter and noeE is inactivated by an interposon (Hanin et al. 1997). Incorporation of labeled sulfate into fucosylated NodNGR factors (Fig. 1C, lane 3) thus confirms earlier suggestions that, while NodH is able to sulfate either the terminal reducing GlcNAc (Ehrhardt et al. 1995) or fucose, NoeE is specific for the latter.

\section{Intracellular localization of sulfotransferase activity.}

Membrane and cytosolic fractions of induced and noninduced cell extracts of ANU265(pA28,pMZBgH) were fractionated by ultra-centrifugation $\left(100,000 \times g, 1 \mathrm{~h}, 4^{\circ} \mathrm{C}\right)$. Sulfotransferase activity of each fraction was assayed by incubating $200 \mu \mathrm{g}$ of the extract with $\left[{ }^{35} \mathrm{~S}\right] \mathrm{PAPS}$ as well as both de-acetylated and de-carbamoylated NodNGR factors. TLC analysis of the methanolic fraction showed that the major sulfotransferase activity was located in the cytosolic fraction (Fig. 2).

\section{Expression of sulfotransferase activity in Escherichia coli and purification of NoeE.}

To purify NoeE, the gene was cloned into the expression vector pMAL-c2 (see Materials and Methods). Sodium dodecyl sulfate-polyacrylamide gel electrophoresis (SDS-PAGE) analysis of total protein extracts of $E$. coli DH5 $\alpha$ containing pMAL-noeE showed that the in-frame insertion of noeE downstream of malE (Fig. 3) resulted in the expression of an isopropyl- $\beta$-D-thiogalactopyranoside (IPTG)-inducible MBPNoeE fusion protein with a predicted mass of $90 \mathrm{kDa}$ (Fig. 4, lane 3). This fusion protein was eluted from an affinity column by maltose (Fig. 4, lane 4) (yield $\cong 7 \mathrm{mg}$ of MBP-NoeE per liter of DH5 $\alpha$ [pMAL-noeE] culture). To further purify NoeE, the fusion protein was fractionated by ion-exchange chromatography on a DEAE Sepharose CL-6B column (Amersham Pharmacia Biotech, Uppsala, Sweden). Sulfotransferase activity was found in several fractions that were pooled and analyzed by SDS-PAGE (Fig. 4, lane 5). NoeE was then released from the appropriate fraction by cleavage with Xa factor, which recognizes the IEGR located between MBP and NoeE. Cleavage produced three major proteins of approximately 47, 43, and $32 \mathrm{kDa}$ (Fig. 4, lane 6). Since NoeE has a predicted molecular mass of $47 \mathrm{kDa}$, the bands at 32 and $43 \mathrm{kDa}$ probably correspond to the $\mathrm{Xa}$ factor and MBP, respectively (Fig. 4, lanes 7 and 8). Surprisingly, the band at 47 $\mathrm{kDa}(\mathrm{NoeE})$ was much less intense than the MBP band at 43 $\mathrm{kDa}$. Similar results were obtained when the gels were stained with silver. Nevertheless, only the MPB-NoeE fusion protein possessed sulfotransferase activity (Fig. 5). Perhaps this suggests that NoeE is relatively unstable, a view that is supported by a protein Param stability index of 46 . It is also possible that the purified enzyme is rapidly denatured. This is suggested by the loss of sulfotransferase activity after cleavage by factor Xa (Fig. 4, lane 6, asterisk, and Fig. 5, lane 3). 
Comparisons of the sulfotransferase activity of MBP-NoeE and cell-free extracts of ANU265(pA28,pMZBgH) to the Nod factors described above did not reveal any differences in substrate specificity (data not shown), suggesting that fusion to MALE has no effect on activity of the enzyme.
Must fucosylated oligochitins be acylated to serve as substrates for NoeE?

In reactions catalyzed by the NGR234 NodZ protein (see Materials and Methods), unlabeled, fucosylated oligochitins (FOCs) were synthesized with $\beta$-GDP-fucose and dimers to

M H K E S

PR1: 5' GGATCCATGCATAAGGAATCGG 3'

PR2: 5' CCCCTGGTGATGATATGCG 3'

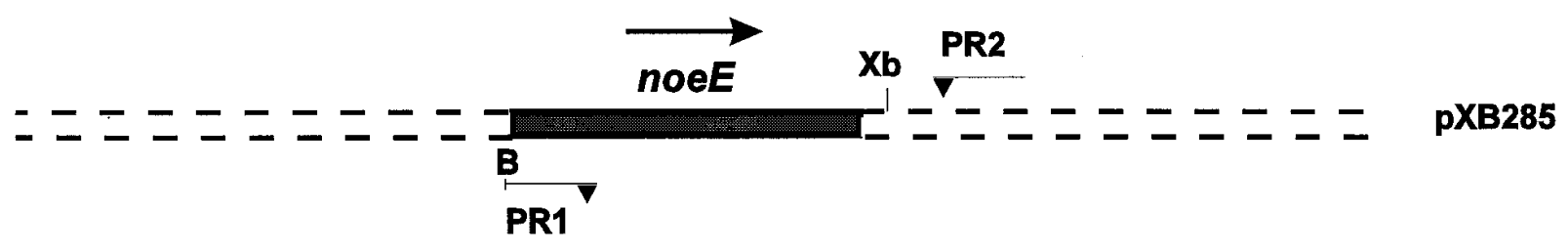

\section{PCR, Xbal digestion and cloning in \\ EcoRV-Xbal sites of pBluescriptKS ${ }^{+}$}

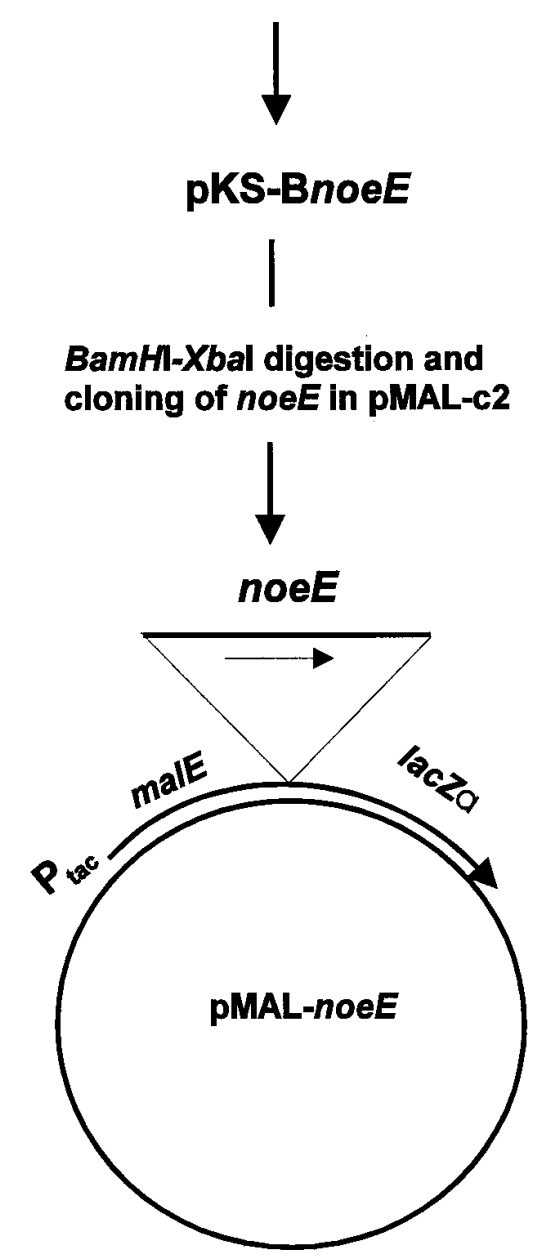

Fig. 3. Construction of pMAL-noeE. A DNA fragment containing the entire noeE open reading frame was amplified by polymerase chain reaction with PR1/PR2 primers and the cosmid pXB285 as template (Perret et al. 1991). Primer PR1 carries a BamHI site that was used for cloning of noeE in frame with malE. Restriction sites: B, BamHI; Xb, XbaI. The bases marked in bold in PR1 represent the BamHI site, and the letters above corrspond to amino acids. 
hexamers of GlcNAc: $\left[(\mathrm{GlcNAc})_{2}\right.$ to $\left.(\mathrm{GlcNAc})_{6}\right]$. Structures of the products were confirmed by electro-spray mass spectrometric analysis, which gave the expected molecular ions $\left[\mathrm{M}+\mathrm{Na}^{+}\right]$at $\mathrm{m} / \mathrm{z}=593, \mathrm{~m} / \mathrm{z}=796, \mathrm{~m} / \mathrm{z}=999$, and $\mathrm{m} / \mathrm{z}=1,202$ (data not shown).

Sulfotransferase activity was assayed as described above, except that the concentrations of $\left[{ }^{35} \mathrm{~S}\right] \mathrm{PAPS}$ and protein extracts were increased two- to 10-fold, and unreacted $\left[{ }^{35} \mathrm{~S}\right] \mathrm{PAPS}$ was removed by anion-exchange chromatography. Cell-free extracts of induced and noninduced $E$. coli DH5 $\alpha$ (pMAL-c2-noeE) or ANU265(pA28,pMZBgH) were unable to transfer sulfate to any of the fucosylated oligochitins. To check that the absence of spots corresponding to sulfated FOCs was not due to the resolving power of the TLC system used, other TLC plates (cellulose-coated and PEIcellulose plates) were also employed without result (data not shown).

Another potential source of error lies in the difficulty of separating the hydrophilic FOCs, unreacted PAPS, and their derivatives from the sulfated products. To circumvent this problem, we prepared ${ }^{14} \mathrm{C}$-labeled FOCs and used them as substrates in sulfation assays with unlabeled PAPS (see Materials and Methods). Silica-gel TLC of the reaction products did not reveal spots corresponding to sulfated oligochitins, even when the reaction products were concentrated by DEAE anion-exchange chromatography (Fig. 6). Nevertheless, when nonfucosylated Nod factors [NodNGR-V $\left(N-\mathrm{Me}, \mathrm{C}_{18: 1}\right.$ or $\left.\left.\mathrm{C}_{18: 0}\right)\right]$ were labeled with $\left[{ }^{14} \mathrm{C}\right]-G D P-f u c o s e$ by NodZ of NGR234 and used as substrates in sulfotransferase assays, sulfated molecules were detected with reverse-phase TLC (data not shown).

Finally, we tested whether methylation was the missing condition for sulfation of the FOCs. To do this, 2-Omethylfucosyl-chitobiose was synthesized chemically (V. Tor-

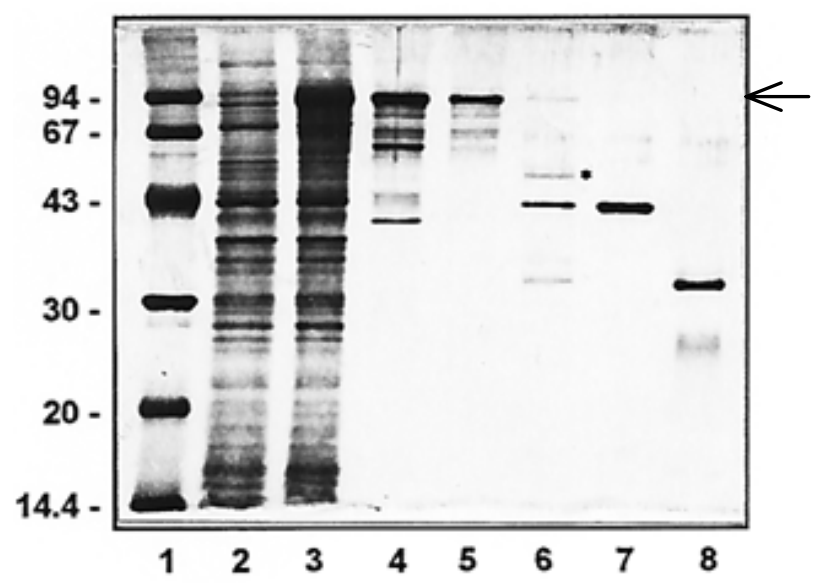

Fig. 4. Coomassie blue-stained sodium dodecyl sulfate-polyacrylamide electrophoresis gel showing purification of NoeE. Lane 1, molecular mass markers (Amersham Pharmacia Biotech, Uppsala, Sweden). Lanes 2 and 3, total proteins of un-induced and isopropyl- $\beta-D-$ thiogalactopyranoside (IPTG)-induced Escherichia coli pMAL-noeE cells. Lane 4, MBP-NoeE fusion protein eluted from an amylose affinity column. Lane 5, MBP-NoeE fusion eluted from DEAE-Sepharose (arrow). Lane 6, MBP-NoeE fusion digested with factor Xa (NoeE indicated by asterisk). Lanes 7 and 8, reference compounds (Bio-Rad Laboratories, Hercules, CA): maltose binding protein (MBP) and factor Xa, respectively. gov, unpublished), and used in standard assays, but the combination 2-O-methylfucosyl-chitobiose and MBP-NoeE did not lead to sulfated products (data not shown). Taken together, these data suggest that only acylated and fucosylated LCOs can serve as substrates for the sulfotransferase encoded by noeE.

\section{DISCUSSION}

Included among the Nod factors secreted by NGR234 are those that are sulfated on $\mathrm{C} 3$ of the fucose group (Price et al. 1992). Here we present further evidence that the sulfotransferase required for sulfation of position $\mathrm{C} 3$ is encoded by noeE. Mutation of noeE abolishes synthesis of sulfated LCOs, while introduction of noeE into the closely related strain USDA257 permits production of sulfated NodRf factors (Hanin et al. 1997).

Although there is surprisingly little homology between the two proteins, NodH thus fulfills a role similar to that of NoeE of NGR234 (Hanin et al. 1997). Nevertheless, NodH is able to confer sulfotransferase activity on an NGR $\Omega$ noE mutant. The

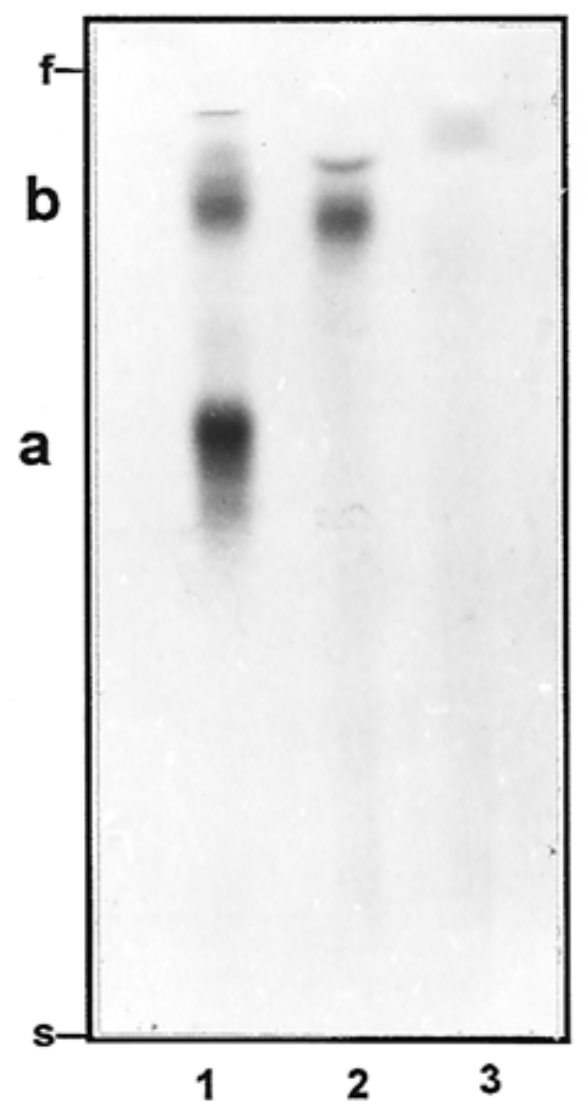

Fig. 5. Reverse-phase thin-layer chromatography (TLC) analysis of products from reactions with the purified NoeE sulfotransferase. Lane 1, NodNGR factors labeled with ${ }^{14} \mathrm{C}$ in vivo. (reference compound, see Figure 1A, lane 1). Lanes 2 and 3, respectively: reaction products formed after incubation with the MBP-NoeE fusion protein (fraction from Figure 4, lane 5) and MBP-NoeE digested with factor $\mathrm{Xa}$ (fraction from Figure 4, lane 6). Reaction mixtures also contained $\left[{ }^{35} \mathrm{~S}\right] 3^{\prime}$ phosphoadenosine $5^{\prime}$-phosphosulfate (PAPS) and deacetylated NodNGR factors (NodNGR-V [ $N$-Me, $\left.\mathrm{C}_{18: 1}, \mathrm{MeFuc}\right]$ ). Nod factors were recovered on $\mathrm{C}_{18}$-SepPacks after incubation. $(\mathrm{s}=$ start point of migration; $\mathrm{f}=$ solvent front). 
major difference between these two proteins appears to be that NodH is able to sulfate both nonfucosylated and fucosylated Nod factors, whereas NoeE is specific for fucosylated Nod factors (Hanin et al. 1997). The in vitro assays reported here confirm this observation.

Biochemical proof that NoeE has sulfotransferase activity in vitro was provided by showing that (i) cell-free extracts of ANU265(pA28,pMZBgH) were able to transfer sulfate from PAPS to fucosylated Nod factors, and (ii) a fraction enriched in NoeE as a fusion protein (MBP-NoeE) has the same capacity (Fig. 4, lane 5). Assays with different substrates showed that neither an $\mathrm{N}$-methyl group, nor saturated or unsaturated fatty acids on the nonreducing terminus, nor 2-O-methyl fucose had any effect on NoeE activity. On the other hand, NoeE is apparently incapable of transferring sulfate to fucosylated oligosaccharides that lack an acyl chain. This contrasts with NodH, which is able to sulfate both acylated and nonacylated oligochitins (Ehrhardt et 1995; Schultze et al. 1995). This apparently absolute requirement of NoeE for a fatty acid on the oligochitins strongly suggests that it must act after the basic Nod factors have been synthesized (i.e., after NodA, which acylates the oligomers). Obviously, NoeE must also act after NodZ has fucosylated the molecules.

Fractionation by high-speed centrifugation showed that, like NodA, NodB, NodL, NodS, and NodZ (Carlson et al. 1994), NoeE is cytosolic. Only NodC is located in the inner cytoplasmic membrane (Barny et al. 1996). It thus seems likely that Nod-factor biosynthesis occurs on the cytosolic side of the cytoplasmic membrane.
A number of sulfotransferases have been isolated from various bacterial, plant, and mammalian species. These include phenol sulfotransferases, heparan sulfotransferases, alcohol sulfotransferases, and amine sulfotransferases (Yamazoe et al. 1994). All are distinct, but so far NoeE is the only known enzyme that is specific for fucosylated LCOs.

\section{MATERIALS AND METHODS}

\section{Bacterial strains, growth conditions,} and cell-free protein extracts.

Bacterial strains and plasmids used in this study are listed in Table 1. Rhizobium strains were grown at $27^{\circ} \mathrm{C}$ in/on RMM3 media (Broughton et al. 1986), using $10^{-6} \mathrm{M}$ apigenin to induce nod genes. E. coli strains were grown in Luria broth supplemented with IPTG $(0.3 \mathrm{mM}$ final concentration) and ampicillin $(100 \mu \mathrm{g} / \mathrm{ml})$. Cell-free extracts of ANU265(pA28), ANU265(pA28,pMZBgH), and E. coli (pMAL-noeE) were prepared by suspending the cells in $10 \mathrm{ml}$ of ice-cold buffer (50 mM Tris-HCl, pH 7.4) supplemented with $1 \mathrm{mM}$ of the protease inhibitor PMSF (phenyl methan-sulfonyl fluoride) and passed through a "French" press. Afterward, the extracts were separated into membrane and cytosolic fractions (Quesada-Vincens et al. 1997).

\section{Purification and labeling of Nod factors.}

NodNGR factors were isolated as described previously (Price et al. 1992; Jabbouri et al. 1995). ${ }^{14}$ C-labeled NodNGR factors were prepared from overnight cultures of NGR234

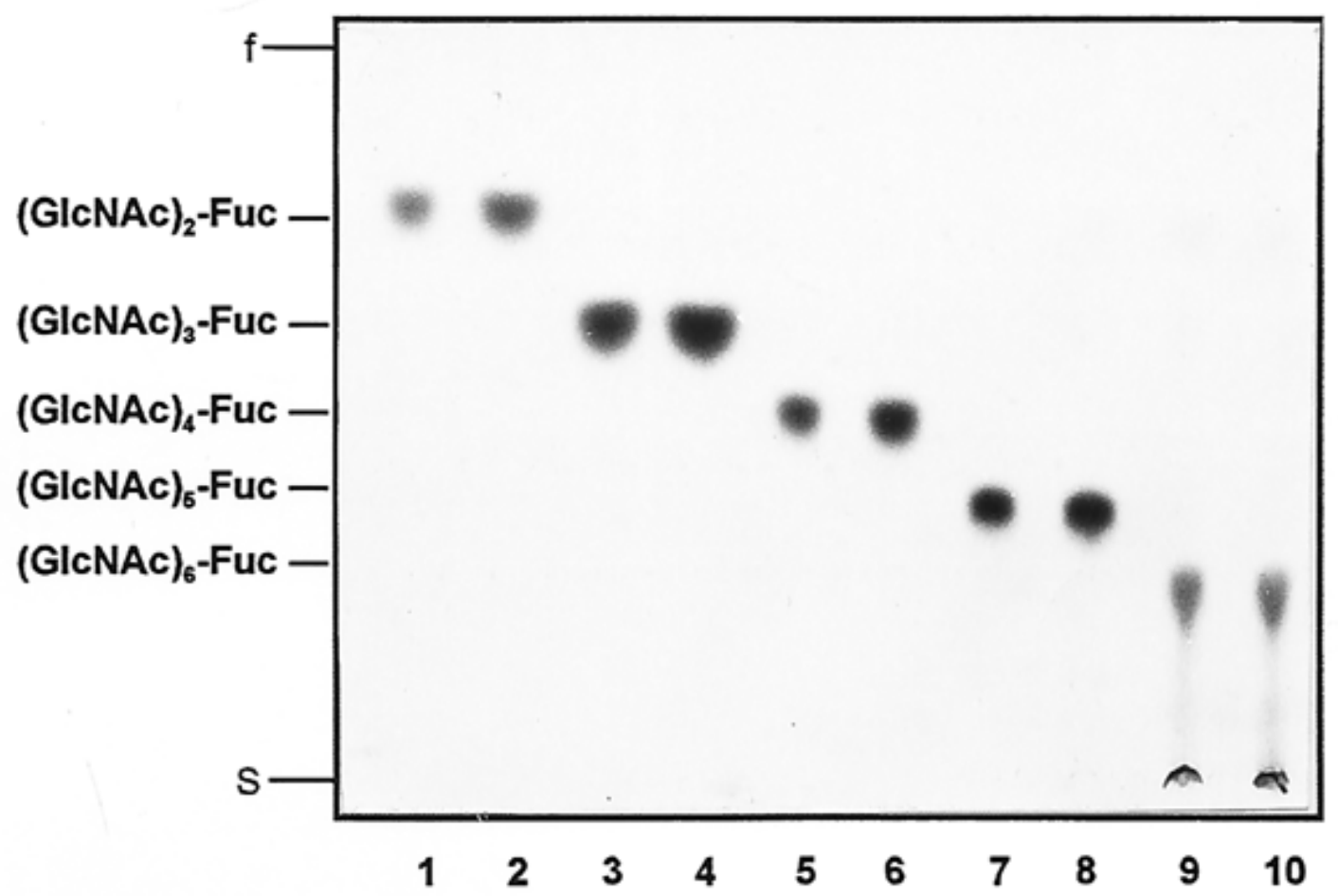

Fig. 6. Silica-gel, thin-layer chromatography (TLC) analysis of sulfotransferase activity with fucosylated oligochitins as substrates. ${ }^{14} \mathrm{C}-$ labeled, fucosylated oligochitins were incubated with $20 \mu \mathrm{g}$ of $3^{\prime}$-phosphoadenosine 5'-phosphosulfate (PAPS) and $300 \mu \mathrm{g}$ of protein extract of DH5 $\alpha$ pMAL-noeE. Lanes 1, 3, 5, 7, and 9: position of the (GlcNAc) $)_{2}$ Fuc, $(\text { GlcNAc })_{3}$ Fuc, $(\text { GlcNAc) })_{4}$ Fuc, $(\text { GlcNAc) })_{5}$ Fuc, and $(\text { GlcNAc })_{6}$ Fuc standards. Lanes 2, 4, 6, 8, and 10: reaction mixtures containing ${ }^{14} \mathrm{C}$-labeled $(\mathrm{GlcNAc})_{2} \mathrm{Fuc},(\mathrm{GlcNAc})_{3} \mathrm{Fuc},(\mathrm{GlcNAc})_{4} \mathrm{Fuc},(\mathrm{GlcNAc})_{5} \mathrm{Fuc}$, or $(\mathrm{GlcNAc})_{6} \mathrm{Fuc}$, respectively. $(\mathrm{s}=$ start point of migration; $\mathrm{f}=$ solvent front). 
grown in the presence of $10^{-6} \mathrm{M}$ apigenin and $1 \mu \mathrm{Ci}$ of $\mathrm{D}-$ $\left[{ }^{14} \mathrm{C}\right]$ glucosamine (specific activity, $54 \mathrm{Ci} / \mathrm{mol}$; Amersham Pharmacia Biotech) (Quesada-Vincens et al. 1997).

\section{Biosynthesis of fucosylated oligochitins.}

Cell-free extracts of E. coli DH5 $\alpha$ (pPROEX-1Z) were the source of fucosyltransferase activity used to synthesizes both radiolabeled and unlabeled fucosylated oligochitins. Labeling reactions in which 100 to $150 \mu \mathrm{g}$ of oligochitins [(GlcNAc $)_{2}$ to $\left.(\mathrm{GlcNAC})_{6}\right]$ were mixed with $0.1 \mu \mathrm{Ci}$ of GDP- $\left[{ }^{14} \mathrm{C}\right]$ fucose $(50 \mathrm{mCi} / \mathrm{mmol}$; DuPont NEN, Boston) and 400 to $600 \mu \mathrm{g}$ of protein extract were performed according to Quesada-Vincens et al. (1997). To synthesize unlabeled, fucosylated oligochitins, $1 \mathrm{mg}$ of di- $N$-diacetylchitobiose (Sigma Chemical, St. Louis, MO), $1 \mathrm{mg}$ of tri- $N$-triacetylchitotriose (Sigma), $2 \mathrm{mg}$ of tetra- $N$-tetraacetylchitotetraose (Sigma), and $5 \mathrm{mg}$ of penta$\mathrm{N}$-pentaacetylchito-pentaose (Seika-gaku, Chuo-ku, Tokyo) were added separately to $500 \mu \mathrm{g}$ of $\beta$-GDP-fucose. After the addition of 3 to $4 \mathrm{mg}$ of cell-free protein extract, the mixture was incubated overnight at $27^{\circ} \mathrm{C}$. Unreacted GDP-fucose was removed by anion-exchange chromatography on DEAESephadex A25 (Amersham Pharmacia Biotech) and the reaction products analyzed by electro-spray-mass spectrometry.

\section{Enzymatic assay of sulfotransferase activity with Nod factors as substrates.}

In $100 \mu \mathrm{l}$ of buffer $\mathrm{A}\left(40 \mathrm{mM} \mathrm{KCl}, 5 \mathrm{mM} \mathrm{MgCl} \mathrm{Mg}_{2}, 50 \mathrm{mM}\right.$ Tris-HCl, $\mathrm{pH} 7.5)$, the reaction mixture contained $1 \mu \mathrm{Ci}$ $\left[{ }^{35} \mathrm{~S}\right]$ PAPS (1.6 Ci/mM; DuPont NEN, Boston), $40 \mathrm{nM}$ candidate sulfate acceptors (Nod factors), and $200 \mu \mathrm{g}$ of cell-free protein extract. Reactions were incubated at $27^{\circ} \mathrm{C}$ for $2 \mathrm{~h}$ and stopped by boiling for $3 \mathrm{~min}$; the nonsoluble material was removed by centrifugation at $10,000 \times g\left(30 \mathrm{~min}, 4^{\circ} \mathrm{C}\right)$. Then, the supernatant was loaded onto $\mathrm{C}_{18}$ SepPack cartridges (Millipore, Milford, MA) and, after washing with water, the Nod factors were eluted with methanol. The methanolic fraction was concentrated by evaporation and separated on $\mathrm{C}_{18}$ reverse-phase TLC plates with 9:1 (vol/vol) methanol/ 5.5 M ammonia as the mobile phase. Autoradiographs were prepared by overlaying the dried TLC plates with Fuji RX film (Fuji Photo Film, Tokyo).

\section{Enzymatic assay of sulfotransferase activity with oligochitins as substrates.}

One sixth of the volume of fucosylated oligochitins, synthesized as described above, was incubated overnight (at $27^{\circ} \mathrm{C}$ ) with 2 to $10 \mu \mathrm{Ci}\left[{ }^{35} \mathrm{~S}\right] \mathrm{PAPS}$ in buffer A. Afterward, the reaction mixture was applied to a DEAE-Sephadex A25 (Amersham Pharmacia Biotech) anion-exchange column equilibrated with water. Step-wise elution with ammonium acetate $\left(10 \mathrm{ml}\right.$ of $0,50,250,750$, and $2 \mathrm{M}$ of $\left.\mathrm{NH}_{4} \mathrm{CH}_{3} \mathrm{COOH}\right)$ removed the majority of the unreacted $\left[{ }^{35} \mathrm{~S}\right] \mathrm{PAPS}$ at a concentration equivalent to $750 \mathrm{mM} \mathrm{NH} \mathrm{CH}_{3} \mathrm{COOH}$. Sulfated lipooligochitins were eluted at an ammonium acetate concentration of $250 \mathrm{mM}$. Sulfation of labeled, fucosylated oligochitins was assayed with 20 or $150 \mu \mathrm{g}$ of unlabeled PAPS in a reaction mixture of $100 \mu 1$. Two microliters of each reaction mixture was spotted onto Silicagel-60 plates. Chromatographyautoradiography with Silicagel-60 HPTLC plates (Merck, Darmstadt, Germany) and butanol/ethanol/ $\mathrm{H}_{2} \mathrm{O}(45 / 30 / 25)$ as the solvent was used to monitor incorporation of $\left[{ }^{35} \mathrm{~S}\right]$ sulfate into fucosylated oligochitins.

\section{Candidate sulfate acceptors and their de-acetylation.}

Potential substrates for the sulfotransferase encoded by noeE included the Nod factors of $R$. fredii strain USDA257 (=

Table 1. Bacterial strains and plasmids $\mathrm{s}^{\mathrm{a}}$

\begin{tabular}{|c|c|c|}
\hline Strain/plasmid & Characteristics & Source/reference \\
\hline \multicolumn{3}{|l|}{ Escherichia coli } \\
\hline $\mathrm{DH} 5 \alpha$ & SupE44DlacU169 (F80lacZDM15)hsdR17recA1 endA1 gyrA96 thi-1 relA1 & Hanahan 1983 \\
\hline \multicolumn{3}{|c|}{ 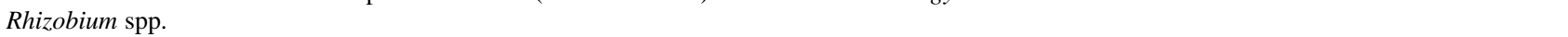 } \\
\hline NGR234 & Rif $^{\mathrm{T}}$ derivative of wild-type strain NGR234, from Lablab purpureus & Trinick 1980 \\
\hline ANU265 & Heat-cured derivative of NGR234 $\left(\mathrm{Sp}^{\mathrm{r}}\right)$ (lacks pNGR234a) & Morrison et al. 1983 \\
\hline ANU265(pA28,pMZBgH) & ANU265 containing $\mathrm{pA} 28,\left(\mathrm{Tc}^{\mathrm{r}}\right)$ and $\mathrm{pMZBgH},\left(\mathrm{Gm}^{\mathrm{r}}\right)$ & This work \\
\hline 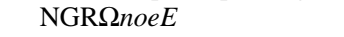 & Insertion mutant of noeE of NGR234 ( $\left.\operatorname{Rif}^{\mathrm{r}}, \mathrm{Sp}^{\mathrm{r}}\right)$ & Hanin et al. 1997 \\
\hline NGR $\Omega$ nodZ & NGR234 carrying an $\Omega$ insertion in the EcoRV site of $n o d Z\left(\mathrm{Rif}^{\mathrm{r}}, \mathrm{Sp}^{\mathrm{r}}\right)$ & Quesada-Vincens et al. 1997 \\
\hline \multicolumn{3}{|c|}{ 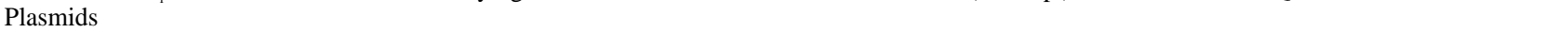 } \\
\hline pBluescriptKS ${ }^{+}$ & phage $\mathrm{f} 1$, lacaZ ${ }^{+}\left(\mathrm{Ap}^{\mathrm{r}}\right)$ & Stratagene, La Jolla, CA \\
\hline Lorist 2 & 5.6-kbp cosmid, $\mathrm{Km}^{\mathrm{r}}$ & Gibson et al. 1987 \\
\hline pRK2013 & $\mathrm{Tra}^{+}$helper plasmid for mobilization, $\left(\mathrm{Km}^{\mathrm{r}}\right)$ & Figurski and Helinski 1979 \\
\hline pBBR1MCS-5 & Broad-host-range cloning vector, $\mathrm{Gm}^{\mathrm{r}}$ & Kovach et al. 1994 \\
\hline $\mathrm{pMZBgH}$ & 3.4-kbp BglII-HindIII fragment containing noeE cloned into pBBR1MCS-5, $\left(\mathrm{Gm}^{\mathrm{r}}\right)$ & Hanin et al. 1997 \\
\hline pMAL-c2 & Protein expression vector, $\left(\mathrm{Ap}^{\mathrm{r}}\right)$ & $\begin{array}{l}\text { New England Biolabs, Bev- } \\
\text { erly, MA }\end{array}$ \\
\hline pMAL-noeE & $\begin{array}{l}\text { 1.4-kbp polymerase chain reaction (PCR) fragment containing noeE cloned into } \\
\text { pMAL-c2, }\left(\mathrm{Ap}^{r}\right)\end{array}$ & This work \\
\hline pProEX-1Z & 1.2-kbp PCR fragment containing nodZ cloned into pProEX-1, $\left(\mathrm{Ap}^{\mathrm{r}} \mathrm{Tc}^{\mathrm{r}}\right)$ & Quesada-Vincens et al. 1997 \\
\hline pProEX-1 & Protein expression vector, $\left(\mathrm{Ap}^{\mathrm{r}}\right)$ & $\begin{array}{l}\text { Life Technologies, Gaith- } \\
\text { ersburg, MD }\end{array}$ \\
\hline pGMI449 & $\begin{array}{l}\text { 2.2-kbp BamHI-BglII fragment carrying nodH of Rhizobium meliloti cloned in } \\
\text { pLAFR3, }\left(\mathrm{Tc}^{\mathrm{r}}\right)\end{array}$ & Debellé and Sharma 1986 \\
\hline pA28 & 2.2-kbp EcoRI-PstI fragment containing nodD1 of NGR234 cloned in pRK7813, $\left(\mathrm{Tc}^{\mathrm{r}}\right)$ & Price et al. 1992 \\
\hline $\mathrm{pXB} 285$ & A Lorist 2 clone from pNGR234a, $\mathrm{Km}^{\mathrm{r}}$ & Perret et al. 1991 \\
\hline pKSB-noeE & 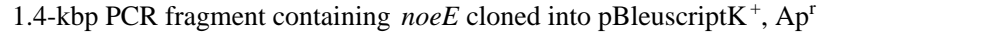 & This work \\
\hline
\end{tabular}

${ }^{a}$ The following abbreviations are used: ampicillin (Ap), gentamycin $(\mathrm{Gm})$, kanamycin $(\mathrm{Km})$, spectinomycine $(\mathrm{Sp})$, and tetracycline $(\mathrm{Tc})$. 
Nod $R f$ ), de-acetylated and de-carbamoylated NodNGR factors [NGR-V ( $N$-Me, $\mathrm{C}_{18: 1}$ or $\left.\left.\mathrm{C}_{18: 0}, \mathrm{MeFuc}\right)\right]$, as well as the fucosylated oligochitins described above. The lipooligochitins of NGR $\Delta$ noeE are oligomers of five GlcNAc residues carrying $\mathrm{N}$-linked acyl $\left(\mathrm{C}_{18: 1}\right.$ or $\left.\mathrm{C}_{18: 0}\right)$ and $\mathrm{N}$-methyl groups and 2-Olinked methyl-fucose [= NGR-V ( $N$-Me, MeFuc, $\mathrm{C}_{18: 1}$, or $\left.\mathrm{C}_{18: 0}\right)$ ]. De-acetylation was performed in $0.2 \mathrm{M} \mathrm{NaOH}\left(37^{\circ} \mathrm{C}\right.$, 1h). Afterward, the reaction mixture was neutralized with 0.2 $\mathrm{M} \mathrm{HCl}$, and applied to a $\mathrm{C}_{18}$ reverse-phase SepPack column, washed with water, and eluted with methanol.

\section{Purification of NoeE.}

noeE was cloned downstream of the malE gene, which encodes a maltose-binding protein. To do this, polymerase chain reaction with the primers $\mathrm{pR}_{1}$ and $\mathrm{pR}_{2}$ was used to amplify noeE and to introduce a BamHI site upstream of the first ATG (see Figure 3). The amplified fragment was then digested with $X b a \mathrm{I}$ and cloned into the EcoRV and $X b a \mathrm{I}$ sites of pBluescript $\mathrm{KS}$, giving pKS-BnoeE. Finally, pKS-BnoeE was digested with Bam HI and $\mathrm{XbaI}$ and the 1.4-kb fragment containing noeE was cloned into the protein expression vector, pMAL-c2 (which in turn, was digested by the same enzymes). Then, this recombinant plasmid, pMAL-noeE, was transformed into $E$. coli DH5 $\alpha$ and the transconjugants screened as described by the manufacturer (New England Biolabs, Beverly, MA). Two hours after induction at $37^{\circ} \mathrm{C}$, the fusion protein, called MBPNoeE, was purified from 1 liter of culture. To do this, the bacteria were recovered by centrifugation, re-suspended in buffer B (20 mM Tris-HCl pH7.4, $200 \mathrm{mM} \mathrm{NaCl,} 1 \mathrm{mM}$ EDTA), containing $1 \mathrm{mM}$ dithiothreitol (DTT) and $1 \mathrm{mM}$ phenylmethane sulfonyl fluoride, and disrupted in a "French" pressure cell. After centrifugation at $10,000 \times g$, the soluble fraction was loaded onto an amylose affinity column (New England Biolabs) pre-equilibrated with buffer B. MBP-NoeE was eluted from this column in buffer B containing $10 \mathrm{mM}$ maltose. MBP-NoeE was then loaded onto a DEAESepharose (Amersham Pharmacia Biotech) column and eluted with a gradient of zero to $500 \mathrm{mM} \mathrm{NaCl}$ in $20 \mathrm{mM}$ Tris- $\mathrm{HCl}$ (pH 8.0). Fractions containing MBP-NoeE were concentrated and desalted with Microcon-10 micro-concentrators (Amicon, Beverly, MA). Finally, $10 \mathrm{mg}$ of this fusion protein was digested with $0.2 \mu \mathrm{g}$ of $\mathrm{Xa}$ factor for $18 \mathrm{~h}$ at $4^{\circ} \mathrm{C}$. After each purification step, the degree of purity was checked by SDSPAGE on $12 \%$ polyacrylamide gels that were stained with Coomassie blue.

\section{ACKNOWLEDGMENTS}

Dora Gerber is thanked for her assistance with many aspects of this work and D. Promé for recording the mass spectra. We are especially indebted to $\mathrm{V}$. Torgov for synthesizing 2-O-methylfucosyl-chitobiose. The Erna och Victor Hasselblads Stiftelse, the Swiss National Science Foundation (Project 31-45921.95), and the Université de Genève provided financial assistance.

\section{LITERATURE CITED}

Atkinson, E. M., Palcic, M. M., Hindsgaul, O., and Long, S. 1994. Biosynthesis of Rhizobium meliloti lipooligosaccharide Nod factors: NodA is required for an $\mathrm{N}$-acyltransferase activity. Proc. Natl. Acad. Sci. USA 91:8418-8422.

Barny, M.-A., Schoonejans, E., Economou, A., Johnston, A. W. B., and Downie, J. A. 1996. The C-terminal domain of the Rhizobium legumi- nosarum chitin synthase NodC is important for function and determines the orientation of the $\mathrm{N}$-terminal region in the inner membrane Mol. Microbiol. 19:443-453.

Bec-Ferté, M.-P., Krishnan, H. B., Promé, D., Savagnac, A., Pueppke, S. G., and Promé, J.-C. 1994. Structures of nodulation factors from the nitrogen-fixing soybean symbiont Rhizobium fredii USDA257. Biochemistry 33:11782-11788.

Broughton, W. J., Wong, C.-H., Lewin, A., Samrey, U., Myint, H., Meyer, z. A., H., Dowling, D. N., and Simon, R. 1986. Identification of Rhizobium plasmid sequences involved in recognition of Psophocarpus, Vigna, and other legumes. J. Cell Biol. 102:1173-1182.

Carlson, R. W., Price, N. P. J., and Stacey, G. 1994. The biosynthesis of rhizobial lipo-oligosaccharide nodulation signal molecules. Mol. Plant-Microbe Interact. 7:684-695.

Cloutier, J., Laberge, S., Castonguay, Y., and Antoun, H. 1996. Characterization and mutational analysis of nodHPQ genes of Rhizobium sp. strain N33. Mol. Plant-Microbe Interact. 9:720-728.

Debellé, F., and Sharma, S. B. 1986. Nucleotide sequence of Rhizobium meliloti RCR2011 genes involved in host specificity of nodulation. Nucleic Acids Res. 14:7453-7472.

Dénarié, J., Debellé F., and Promé, J.-C. 1996. Rhizobium lipo-chitooligosaccharide nodulation factors: Signalling molecules mediating recognition and morphogenesis. Annu. Rev. Biochem. 65:503-535.

Ehrhardt, D. W., Atkinson, E. M., Faull, K. F., Freedberg, D. I., Sutherlin, D. P., Armstrong, R., and Long, S. R. 1995. In vitro sulfotransferase activity of NodH, a nodulation protein of Rhizobium meliloti required for host-specific nodulation. J. Bacteriol. 177:6237-6245.

Ehrhardt, D. W., Atkinson, E. M., and Long, S. R. 1992. Depolarization of alfalfa root hair membrane potential by Rhizobium meliloti Nod factors. Science 256:998-1000.

Ehrhardt, D. W., Wais, R., and Long, S. R. 1996. Calcium spiking in plant root hairs responding to Rhizobium nodulation signals. Cell 85: 673-681.

Faucher, C., Maillet, F., Vasse, J., Rosenberg, C., van Brussel, A. A. N., Truchet, G., and Dénarié, J. 1988. Rhizobium meliloti host range $n o d H$ gene determines production of an alfalfa-specific extracellular signal. J. Bacteriol. 170:5489-5499.

Figurski, D. H., and Helinski, D. R. 1979. Replication of an origincontaining derivative of plasmid RK2 dependent on a plasmid function provided in trans. Proc. Natl. Acad. Sci. USA 76:1648-1652.

Folch-Mallol, J. L., Marroqui, S., Sousa, C., Manyani, H., López-Lara, I. M., van der Drift, K. M. G. M., Haverkamp, J., Quinto, C., GilSerrano, A., Thomas-Oates J., Spaink, H. P., and Megías, M. 1996. Characterization of Rhizobium tropici CIAT899 nodulation factors: The role of $n o d H$ and $n o d P Q$ genes in their sulfation. Mol. PlantMicrobe Interact. 9:151-163.

Geelen, D., Leyman, B., Mergaert, P., Klarskov, K., van Montagu, M., Geremia, R., and Holsters, M. 1995. NodS is an S-adenosyl-Lmethionine-dependent methyltransferase that methylates chitooligosaccharides deacetylated at the non-reducing end. Mol. Microbiol. 17: 387-397.

Gehring, C. A., Irving, H. R., Kabbara, A. A., Parish, R. W., Boukli, N. M., and Broughton, W. J. 1997. Rapid, plateau-like increases in intracellular free calcium are associated with Nod-factor-induced root-hair deformation. Mol. Plant-Microbe Interact. 10:791-802.

Geremia, R. A., Mergaert, P., Geelen, D., van Montagu, M., and Holsters, M. 1994. The NodC protein of Azorhizobium caulinodans is an $\mathrm{N}$-acetylglucosaminyltransferase. Proc. Natl. Acad. Sci. USA 91: 2669-2673.

Gibson, T. J. A., Coulson, A. R., Sulston, J. E., and Little, P. F. R. 1987. Lorist2, a cosmid with transcriptional terminators insulating vector genes from interference by promoters within the insert: effect on DNA yield and cloned insert frequency. Gene 53:275-281.

Hanahan, D. 1983. Studies on transformation of Escherichia coli with plasmids. J. Mol. Biol. 166:557-580.

Hanin, M., Jabbouri, S., Broughton, W. J., Fellay, R., and QuesadaVincens, D. Molecular aspects of host-specific nodulation. In: PlantMicrobe Interactions 1998. G. Stacey and N. T. Keen, eds. American Phytopathological Society, St. Paul, MN. (In press).

Hanin, M., Jabbouri, S., Broughton W. J., and Fellay, R. 1998. SyrM1 of Rhizobium sp. NGR234 activates transcription of symbiotic loci and controls the level of sulfated Nod-factors. Mol. Plant-Microbe Interact. 11:343-350.

Hanin, M., Jabbouri, S., Quesada-Vincens, D., Freiberg, C., Perret, X., 
Promé, J.-C., Broughton, W. J., and Fellay, R. 1997. Sulphation of Rhizobium sp. NGR234 Nod factors is dependent on noeE, a new host-specificity gene. Mol. Microbiol. 24:1119-1129.

Heidstra, R., Geurts, R., Franssen, H., Spaink, H. P., van Kammen, A., and Bisseling, T. 1994. Root hair deformation activity of nodulation factors and their fate on Vicia sativa. Plant Physiol. 105:787-797.

Jabbouri, S., Fellay, R., Talmont, F., Kamalaprija, P., Burger, U., Relić, B., Promé, J.-C., and Broughton, W. J. 1995. Involvement of nodS in $\mathrm{N}$-methylation and nodU in 6-O-carbamoylation of Rhizobium sp. NGR234 Nod factors. J. Biol. Chem. 270:22968-22973.

Jabbouri, S., Relić, B., Hanin, M., Kamalaprija, P., Burger, U., Promé, D., Promé, J.-C., and Broughton, W. J. 1998. nolO and noeI (HsnIII) of Rhizobium sp. NGR234 are involved in 3-O-carbamoylation and 2$O$-methylation of Nod-factors. J. Biol. Chem. 273:12047-12055.:

Kovach, M. E., Phillips, R. W., Elzer, P. H., Roop, R. M., II, and Peterson, K. M. 1994. pBBR1MCS: A broad-host-range cloning vector. Biotechniques 16:800-802.

Krishnan, H. B., Lewin, A., Fellay, R., Broughton, W. J., and Pueppke, S. G. 1992. Differential expression of nodS accounts for the varied abilities of Rhizobium fredii USDA257 and Rhizobium sp. strain NGR234 to nodulate Leucaena spp. Mol. Microbiol. 6:3321-3330.

Laeremans, T., Caluwaerts, I., Verreth, C., Rogel, M. A., Vanderleyden, J., and Martinez-Romero, E. 1996. Isolation and characterization of the Rhizobium tropici Nod factor sulfation genes. Mol. Plant-Microbe Interact. 9:492-500.

Lewin, A., Cervantes, E., Wong, C.-H., and Broughton, W. J. 1990. nodSU, two new nod genes of the broad host range Rhizobium strain NGR234 encode host-specific nodulation of the tropical tree Leucaena leucocephala. Mol. Plant-Microbe Interact. 3:317-326.

Lorquin, J., Lortet, G., Ferro, M., Mear, N., Promé, J.-C., and Boivin, C. 1997. Sinorhizobium teranga bv. Acaciae ORS1073 and Rhizobium sp. srain ORS1001, two distantly related acacia-nodulating strains, produce similar Nod-factors that are $O$-carbamoylated, $N$-methylated, and mainly sulfated. J. Bacteriol. 179:3079-3083.

Mergaert, P., van Montagu, M., and Holsters, M. 1997. Molecular mechanisms of Nod factor diversity. Mol. Microbiol. 25:811-817.

Morrison, N. A., Hau, C. Y., Trinick, M. J., Shine, J., and Rolfe, B. G. 1983. Heat curing of a Sym plasmid in a fast-growing Rhizobium sp. that is able to nodulate legumes and the nonlegume Parasponia sp. J. Bacteriol. 153:527-531.

Perret, X., Broughton, W. J., and Brenner, S. 1991. Canonical ordered cosmid library of the symbiotic plasmid of Rhizobium species NGR234. Proc. Natl. Acad. Sci. USA 88:1923-1927.

Poupot, R., Martinez-Romero, E., and Promé, J.-C. 1993. Nodulation factors from Rhizobium tropici are sulfated or non-sulfated chitopentasaccharides containing an $N$-methyl- $N$-acylglucosamine terminus. Biochemistry 32:10430-10435.
Price, N. P. J., Relić, B., Talmont, F., Lewin, A., Promé, D., Pueppke, S. G., Maillet, F., Dénarié, J., Promé, J.-C., and Broughton, W. J. 1992. Broad-host-range Rhizobium species strain NGR234 secretes a family of carbamoylated and fucosylated nodulation signals that are $O$ acetylated or sulfated. Mol. Microbiol. 6:3575-3584.

Quesada-Vincens, D., Fellay, R., Nasim, T., Viprey, V., Burger, U., Promé, J.-C., Broughton, W. J., and Jabbouri, S. 1997. Rhizobium sp. NGR234 NodZ protein is a fucosyltransferase. J. Bacteriol. 16:50875093.

Relić, B., Perret, X., Estrada-Garcia, M. T., Kopcinska, J., Golinowski, W., Krishnan, H. B., Pueppke, S. G., and Broughton, W. J. 1994. Nod factors of Rhizobium are a key to the legume door. Mol. Microbiol. 13:171-178.

Roche, P., Debellé, F., Maillet, F., Lerouge, P., Faucher, C., Truchet, G., Dénarié, J., and Promé, J.-C. 1991. Molecular basis of symbiotic host specificity in Rhizobium meliloti: nodH and nodPQ genes encode the sulfation of lipochito-oligosaccharide signals. Cell 67:1131-1143.

Schultze, M., and Kondorosi, A. 1996. The role of lipochitinoligosaccharides in root nodule organogenesis and plant cell growth. Curr. Opin. Gen. Dev. 6:631-638.

Schultze, M., Staehelin, C., Röhrig, H., John, M., Schmidt, J., Kondorosi, E., Schell, J., and Kondorosi, A. 1995. In vitro sulfotransferase activity of Rhizobium meliloti NodH protein: Lipochitooligosaccharide nodulation signals are sulfated after synthesis of the core structure. Proc. Natl. Acad. Sci. USA 92:2706-2709.

Schwedock, J. S., Liu, C., Leyh, T. S., and Long, S. R. 1994. Rhizobium meliloti NodP and NodQ form a multifunctional sulfate-activating complex requiring GTP for activity. J. Bacteriol. 176:7055-7064.

Spaink, H. P., Wijfjes, A. H. M., van der Drift, K. M. G. M., Haverkamp, J., Thomas-Oates, J. E., and Lugtenberg, B. J. J. 1994. Structural identification of metabolites produced by the NodB and NodC proteins of Rhizobium leguminosarum. Mol. Microbiol. 13: 821-831

Trinick, M. J. 1980. Relationships amongst the fast-growing Rhizobium of Lalab purpureus, Leucarena leucocephala, Mimosa sp., Acacia farnesiana, and Sesbania grandiflora and their affinities with other Rhizobium groups. J. Appl. Bacteriol. 49:39-53.

Truchet, G., Roche, P., Lerouge, P., Vasse, J., Camut, S., de Billy, F., Promé, J.-C., and Dénarié, J. 1991. Sulphated lipo-oligosaccharide signals of Rhizobium meliloti elicit root nodule organogenesis in alfalfa. Nature 351:670-673.

Waelkens, F., Voets, T., Vlassak, K., Vanderleyden, J., and van Rhijn, P. 1995. The nodS gene of Rhizobium tropici strain CIAT899 is necessary for nodulation on Phaseolus vulgaris and Leucaena leucocephala. Mol. Plant-Microbe Interact. 8:147-154

Yamazoe, Y., Nagata, K., Ozawa, S., Kato, R. 1994. Structural similarity and diversity of sulfotransferases. Chem.-Biol. Interact. 92:107-117. 